\title{
DISTRIBUTION OF ALLUSIONS IN BRITISH MODERNIST PROSE: STATISTICAL APPROACH
}

\author{
Iryna Zadorozhna, Oksana Yarema, Olha Ladyka ${ }^{1}$
}

\begin{abstract}
The current study is dedicated to the analysis of the distribution of allusions in the texts of the British modernist writers. Even though a lot of linguistic researches were carried out in this field, the statistical aspect has not been set as the primary one in the analysis of allusions so far. The material used for the investigation is based on the ten randomly chosen excerpts of texts of seven authors (70 excerpts in general).The selection of material was carried out according to determined linguistic criteria.To obtain statistically significant results a series of calculations was appliedand mainly Student's t-test showed the distance between the analysed pairs of authors and the allusive load of their texts. For the reason of identifying extralinguistic influence onto the volume of allusions found in the texts, we decided to differentiate between eight types of allusions: mythological, theological, literary, historical and social, folklore, everyday-life, art and personal. It can be clearly stated that the projection of biblical, historical or literary plots in the fiction of the British modernist authors reflects the current mood of the epoch as well as individual authors' styles and intertextual correlation of their works with the previous literary texts. The results showed that the epic genre is characterised by literary, theological, historical and personal types of allusions. The predominance of theological, literary and everyday-life types of allusions is found in the texts of J. Joyce, literary and historical types - in A. Huxley's works, historical type - G. Orwell, literary $\mathrm{V}$. Woolf. With the help of the obtained indicators, the results of this study showed that the divergence insignificance is valid for all analysed pairs, with the exception of the opposition of the texts by A. Huxley and V. Woolf $(0,02)$ and G. Orwell - S. Maugham $(0,52)$ in the theological type of allusions, A. Huxley and H. Lawrence $(0,1)$ and A. Huxley and J. Conrad $(0,1)$ in the literary type. Moreover, the structural form of the text and syntactic patterns seem to affect the allusive load that is proven by the comparison of the drama and epic genres of S. Maugham.
\end{abstract}

\section{Keywords}

Allusion, intertext, Modernism, t-test, statistical significance.

1. Introduction. The interest of researchers in theallusion as a marker of intertexual interaction stipulated the formation of a new look at the dialogical text interaction or the theory of intertextuality in the middle of the last century. Adjacent to allusion notions, among which quotation, reminiscence, and paraphrase are singled out that serve as a coherent link of intertextual dependence and express its properties, create an intertextual conglomeration characterized by the propensity to linguistic and conceptual diffusion. The linguists who tried to set the definitive and functional boundaries belong both to the domestic and foreign schools (M. Vorobieva, A. Lavrynenko O. Perelomova, L. Statkevich, R. Chornovol-Tkachenko, M. Shapoval, P. Allan, Z. Ben-Porat, M. Viller, W. Irwin, P. Lennon, V. Moskvin, S. Pokhodnya, N. Semenova, I. Smirnov, E. Khaliziev, J. Hollander et al.). With the new approaches and areas of research - intertextual, linguistic, literary, linguo-cultural, stylistic, cognitive, semiotic, communicative-pragmatic, translation studies - the nature and properties of these concepts, the boundaries of their intertextual attribution changed depending on the requirements of time, available work and research material, but still remain controversial. Such a versatile approach and scale of work in the field of study of the allusion seems to leave no space for scientific observations and exploration in linguistic science. Despite the considerable base of theoretical searches for the essence of the allusion, its semantic correlation with the precedent text and metatext, the statistical vector of the study of allusion remained in the spotlight. It is worth mentioning that in the last decade many domestic and foreign scholars tend to direct their linguistic researches into the field of statistics, e.g. phonetic data (Pigoli D. et al, 2018) ${ }^{2}$, poetic texts (Popescu, 2015, Aleksienko, Darchuk, 2004) ${ }^{3}$, sentence length frequencies (Pande, Hoshiyar, 2016) ${ }^{4}$, part-of-speech

\footnotetext{
${ }^{1}$ Prof., Dr. N. I. Zadorozhna, Ternopil Volodymyr Hnatiuk National Pedagogical University, M. Kryvonosa, 2a, 46027-Ternopil, Ukraine, Email: irynazadorozhnai@gmail.com. ORCID ID: 0000-0003-1599-1372

Ass.Prof., PhD. O. Yarema, Ternopil Volodymyr Hnatiuk National Pedagogical University, M. Kryvonosa, 2a, 46027-Ternopil, Ukraine, Email: yarema-te@ukr.net.ORCID ID: 0000-0001-7103-8565

Ass.Prof., PhD. O. Ladyka, Ternopil Volodymyr Hnatiuk National Pedagogical University, M. Kryvonosa, 2a, 46027-Ternopil, Ukraine, Email: olha.ladyka@gmail.com. ORCID ID: 0000-0003-1844-1739

${ }^{2}$ Pigoli, D. et al. (2018). The statistical analysis of acoustic phonetic data: exploring differences between spoken Romance languages. In : Journal of the Royal Statistical Society: Series C (Applied Statistics), 67 (Part 4), pp. 1-27

${ }^{3}$ Popescu, I.-I. (2015). Quantitative Analysis of Poetic Texts. Walter De Gruyter Incorporated; Aleksiienko L. A. (2003). Pryntsypy stvorennia parametryzovanoi bazy danykh za poetychnymy tekstamy Lesi Ukrainky. In Ukrainka i suchasnist (do 130-richchia vid dnia narodzhennia Lesi Ukrainky) : zb. nauk. prats. Lutsk : Volyn. obl. druk., pp. 344-352.
} 
frequencies in literary texts (Rovenchak, 2018) ${ }^{5}$, verb characteristics in fiction (Zhukovska, 2006) ${ }^{6}$, as well as dedicated their investigations in describing the application of statistics in linguistic field in general, e.g. Statistical Methods in Language and Linguistic Research (Pascual, 2017) ${ }^{7}$, Statistics for linguistics with $R$ : A practical introduction (Gries, 2013) ${ }^{8}$, Quantitative methods in linguistics (Johnson, 2008), Analyzing linguistic data: A practical introduction to statistics using $R$ (Baayen, $2008)^{10}$. Thus, the aim of the research is to reveal the differences in the distribution of the allusion in the texts of authors belonging to the period of Modernism using statistical methods.

\section{Methodology.}

2.1. Material selection criteria. The primary step in receiving objective data lies in the formation of linguistically and statistically appropriate material out of the text fragments of various authors. The criteria chosen for the formation of the bank of text samples should ensure that the excerpts of texts for the analysis are homogeneous and formed under the qualitative selection of the material. It is obvious that the primary method is that of consecutive analysis, however, the features of the units to be identified in an array of a text are also taken into account.

Ukrainian scientist O. Demska-Kulchytska states that the array of a text, which consists of the same number of passages of texts, is similar to the criteria and requirements for the selection of the material to form a text corpus (Demska-Kulchytska) ${ }^{11}$. Therefore, the selection of material was carried out according to the following criteria that we use in a series of our investigations:

1) diachronic - texts belong to one time period, which lasted from the end of the nineteenth century until the middle of the twentieth century and was united by the literary trend of modernism;

2) representative - the texts reproduce the actual state of the language during the aforementioned period, preserving the author's or territorial features of the language;
3) stylistic - texts combine works, expressed in prosaic form, among which primarily novels were selected;

4) authentic - all texts are unmodified and unadapted, so they reflect the real state of the language and the organization of the work;

5) quantitative - the number of words in the passages (samples) is clearly defined and fluctuates within 100 word forms.

The formation of the corresponding subsamples in the epic genre was characterized by the selection of subsamples with the number of units in 1000 word forms. Thus, it was taken 10 excerpts out of the texts of seven authors (J. Joyce, A. Huxley, H. Lawrence, V. Woolf, G. Orwell, S. Maugham and J. Conrad).

In the theory of statistics there can be found various methods for sampling of a population (the simple random sampling, cluster sampling, stratified sampling, systematic sampling, quota sampling, etc) (Upton, Cook, 2001, 80-84) ${ }^{12}$. Beside, statistical methods of linguistics are widely used in modern studies of language phenomena of different levels (Baayen, 2008).

Parameters and formulas used in mathematical statistics in the theory of linguistic statistics often have a simplified form. This is due to the fact that linguistic statistics require somewhat less precision in the results of the research than the mathematical, technical or physical calculations.

It is impossible to predict the appearance of a phenomenon, therefore, in statistics the occurrence of any phenomenon is considered to be random, because we can not predict in advance the number of its occurrence in the following passage (Johnson, 2008, 20).

Since the method of random sampling is chosen as the initial stage of the research, we refer to the statement of V. I. Perebyinis notes that the reason for the recognition of a random sample as the one giving reliable results of the study is the hypothesis that a sufficiently large number of randomly selected units from the general population should adequately represent it. The random sample corresponds to the cardinal position of the

\footnotetext{
${ }^{4}$ Pande, H., Hoshiyar D. (2015). Determination of the Distribution of Sentence Length Frequencies for Hindi Language Texts and Utilization of Sentence Length Frequency Profiles for Authorship Attribution. In Journal of Quantitative Linguistics, 22 (4), pp. 338-348

${ }^{5}$ Rovenchak, A., Buk S. (2018). Part-of-Speech Sequences in Literary Text: Evidence From Ukrainian. In Journal of Quantitative Linguistics, 25 (1), pp. 1-21.

${ }^{6}$ Zhukovska, V. V. (2006) Leksyko-semantychni ta prahmatychni kharakterystyky anhliyskoho diyeslova u khudozhniomu teksti: linhvo-statystychnyi aspect (na materiali populiarnykh politychnukh romaniv) : dys. ... kand. filol. nauk: 10.02.04. Kyiv.

${ }^{7}$ Pascual, C.G. (Ed.) (2013). Statistical Methods in Language and Linguistic Research. UK: Equinox Publishing Ltd.

${ }^{8}$ Gries, Stefan Th. Statistics for linguistics with R: A practical introduction (2nd, revised edition). Berlin \& Boston, MA: De Gruyter Mouton, 2013.

${ }_{9}^{9}$ Johnson K. (2008) Quantitative methods in linguistics. Malden: Blackwell Publishing.

${ }^{10}$ Baayen, Harald R. (2008). Analyzing linguistic data: A practical introduction to statistics using R. Cambridge: Cambridge University Press.

${ }^{11}$ Demska-Kulchytska, O. Shcho take korpus tekstiv? [Electronic resource]. - Access mode: http://kulturamovy.univ.kiev.ua/ $\mathrm{KM} / \mathrm{pdfs} /$ Magazine64-7.pdf

${ }^{12}$ Upton, G., Cook I. (2001). Introducing Statistics. Oxford: Oxford University Press.
} 
statistics about the randomness of the events that are being considered by it (Perebyinis 2002, 20) ${ }^{13}$.

One of the most important preconditions of the statistical research is the defining of the distribution of random variables. But in linguistic statistics it is a priori accepted that the distribution of the analysed items is subordinated to the normal one. However, in order to get reliable results, the number of the analysed items should sufficient (Levytskyi, 2007, 103) ${ }^{14}$.

In this research we deal only with 70 subsamples of an epic genre of literature to show the difference in the allusive load in the works of various authors. According to the table of "Sufficiently large numbers", such a number of samples will ensure the reliability of the results $(p)$ at $99 \%$ and a relative error $(e)$ of $0.09 \%$, which is completely satisfactory for linguistic research (Holovin 1977, 57) ${ }^{15}$. Indeed, as noted by B. M. Holovin, the experience of involving statistics in studying the main phenomena of morphology and syntax in different styles of literary language convinces that in order to obtain sufficiently reliable data of mean values and proportions, the number of $10-20$ samples with volume in 500 words is enough to carry out the research. However, low frequency phenomena require a greater number of observations of the investigated frequency and proportion (Holovin 1977, 58).

2.2. The description of the statistical aspect of the research

Epic genre of the period of Modernism is characterized by the average degree of allusiveness in comparison to lyric and drama. In addition, the allusion as an expressive means, is characterized by different thematic features, the study of functioning of which can help to understand the specifics of the speech of each author.

The texts of J. Joyce ("Ulysses", "Dubliners", "A Portrait of an Artist as a Young Man", "Finnegan's Wake"), A. Huxley ("Brave New World", "Crome Yellow", "Point. Counter Point", "Ape and Essence"), H. Lawrence ("Aaaron's Rod", "Women in Love","Lady Chatterley's Lover","The Rainbow" "The Lost Girl"), V. Woolf ("The Voyage Out", "Jacob's Room", "Night and Day", "A Room of One's Own",To the Lighthouse", "The Waves"), G. Orwell ("Burmese Days", "Animal Farm", "Nineteen Eighty-Four","Coming Up for Air"), S. Maugham ("Of Human Bonage", "The Painted Veil", "Cakes and Ale", "The Magician", "The Explorer") and J. Conrad ("The Arrow of Gold", "The Rescue", "The Shadow Line" "The Secret Agent", "The Victory") were chosen for the analysis. The total number of allusions found in fiction analysed is 293 , whereas mythological allusions are represented by 9 units, literary -82 , theological -66 , historical and social -49 , folklore 11 , everyday life -21 , art -5 and personal -50 .
The statistical aspect of the research includes the following stages:

- the calculation of the sample mean of the eight types of allusions in the texts of each author with the formula $\bar{x}=\frac{\sum n_{i} x_{i}}{\sum n_{i}}$, where $\sum$ is sum of all data values, $x_{i}$ - each of the values in a subsample (total number of subsamples for each author is 10$) ; n_{i}$ - number of subsample with data value $x_{i}$.

- Then the standard deviation of the population is counted using the formula

$$
\sigma=\sqrt{\frac{\sum\left(x_{i}-\bar{x}\right)^{2}}{\sum n_{i}} .}
$$

Confidence intervals are calculated with the formula $\bar{x}-2 \sigma$ and $\bar{x}+2 \sigma$. They are used to calculate upper and lower $95 \%$ limits. If $95 \%$ of the received values do not exceed these limits, then the samples are homogeneous.

- The standard error of the sample mean is the next step: $\sigma_{\bar{x}}=\frac{\sigma}{\sqrt{n}}$, where $\mathrm{n}=\sum_{n_{i}}$; together with calculating $\varepsilon=\frac{1,96 * \sigma_{\bar{x}}}{\bar{x}}$.

- To use the t-test it is necessary to calculate the standard deviation of the mean:

$$
S_{\bar{x}}=\sqrt{\frac{\sum\left(x_{i}-\bar{x}\right)^{2} n_{i}}{N(N-1)} .}
$$

Student's $t$-test is used for assessing the statistical significance of the difference between two samplemeans and counting the distance between them if any. For calculating the statistical significance between them we use the formula

$$
t=\frac{|\bar{x}-\bar{y}|}{\sqrt{s_{\bar{x}}^{2}}+s_{\bar{y}}^{2}} .
$$

In order to establish where the received value indicates of the significance of the difference, it is necessary to refer to the table of the critical values of the Student, having predefined the number of degrees of freedom: $\mathrm{f}=n_{x}+n_{y}$. The table contains several values. If empirical $t \geq t_{a 1 \%}$ in the table, then it can be assured with $99 \%$ confidence that the difference is significant. Then on the last stage it is possible to calculate the distance:

$$
l=\frac{t-t_{a}}{t},
$$

where $t$-empirical value, and $t_{a}$ - table value of a given confidence probability.

\footnotetext{
${ }^{13}$ Perebyinis, V. I. (2002). Statystychni metody dlia linhvistiv. Vinnytsia: Nova knyha.

${ }^{14}$ Levytskyi, V.V. (2007). Kvantitativnie metody v lingvistike. Vinnytsia: Nova knyha.

${ }^{15}$ Holovin, B. N. (1977). Vvedenie v jazikoznaniye. Moskva: Vussh. shk.
} 
3. Results and Discussion.The statistical beginning of the research starts with the counting of the sample mean of different types of allusions in the samples of each separate author. In the research such thematic types of allusions as mythological (M), theological (T), literary (L), historical and social (H), folklore (F), everyday-life (EL), art (A) and personal (P) are distinguished. The received data are:

- in J. Joyce's texts $(\mathrm{M}-0.50 ; \mathrm{T}-2.5 ; \mathrm{L}-3.4$; $\mathrm{H}-1.1 ; \mathrm{F}-0.7 ; \mathrm{EL}-1.7 ; \mathrm{A}-0.2 ; \mathrm{P}-1.2)$;

in A. Huxley's texts $(\mathrm{M}-0.3 ; \mathrm{T}-1.1 ; \mathrm{L}-1.3$; $\mathrm{H}-1.7 ; \mathrm{F}-0.1 ; \mathrm{EL}-0 ; \mathrm{A}-0.2 ; \mathrm{P}-1.2)$;

- in $\mathrm{H}$. Lawrence's texts $(\mathrm{M}-1.1 ; \mathrm{T}-1.4$; $\mathrm{L}-0.1 ; \mathrm{H}-0.1 ; \mathrm{F}-0.3 ; \mathrm{EL}-0 ; \mathrm{A}-0 ; \mathrm{P}-0.2)$;

- in V. Woolf's texts $(\mathrm{M}-0 ; \mathrm{T}-0 ; \mathrm{L}-2.2$; $\mathrm{H}-0.1 ; \mathrm{F}-0 ; \mathrm{EL}-0 ; \mathrm{A}-0 ; \mathrm{P}-0.7)$;

- in G. Orwell's texts $(\mathrm{M}-0 ; \mathrm{T}-1 ; \mathrm{L}-0.6$;

$\mathrm{H}-1.7 ; \mathrm{F}-0 ; \mathrm{EL}-0.2 ; \mathrm{A}-0 ; \mathrm{P}-0.7)$;

- in S. Maugham's texts $(\mathrm{M}-0 ; \mathrm{T}-0.2 ; \mathrm{L}-0.5$;

$\mathrm{H}-0.2 ; \mathrm{F}-0 ; \mathrm{EL}-0.2 ; \mathrm{A}-0.1 ; \mathrm{P}-1)$

- and J. Conrad's texts $(\mathrm{M}-0 ; \mathrm{T}-0.5 ; \mathrm{L}-0.1$; $\mathrm{H}-0 ; \mathrm{F}-0$; $\mathrm{EL}-0 ; \mathrm{A}-0 ; \mathrm{P}-0)$.

Sample means presented above show the concentration in the distribution of separate types of allusion found in the texts of various authors, such as J. Joyce, A. Huxley, H. Lawrence and G. Orwell. Radically different are the data of theological, literary and everyday-life types of allusions in J. Joyce's texts. For
A. Huxley's texts the nucleus of allusions is formed out of the literary and historical types. In the texts of G. Orwell the key is the historical type of allusion. Drastically different and high is the number of literary allusions in the text of V. Woolf. The prose of S. Maugham and J. Conrad contains a mere distribution of allusions.

Thus, the epic genre is characterised by literary, theological, historical and personal types of allusion. The statistical calculation help to show whether there is a difference in the distribution of allusions between separate subsamples of the authors.

3.1. Mythological type. The presence of this type of allusion with the minimum difference between the sample means is found in the samples of only three authors - J. Joyce, A. Huxley and H. Lawrence.

The standard error of the sample mean $\left(\delta_{\bar{x}}\right)$ equals 0,21 for allusions in J. Joyce's texts; 0,20 - for A. Huxley's texts; $0,09-$ for H. Lawrence's texts.

Confidence intervals $\bar{x}-2 \delta_{-}$to $\bar{x}+2 \delta_{\bar{x}}$ fluctuate between 0,08 and 0,92 (at ${ }^{x} \%-99,17 \%$ ) in J. Joyce's text; from 0,00 to 0,71 (at $\varepsilon \%-98,68 \%$ ) in A. Huxley's fiction; from 0,00 to 0,29 (at $\varepsilon \%-$ $98,14 \%)$ - in H. Lawrence's texts. In general, the level of upper bound of fluctuations is the same in the texts of these authors. The data of the confidence intervals are presented visually on the diagram (fig. 1).

The distribution of different types of independent FI is presented in Table 1.

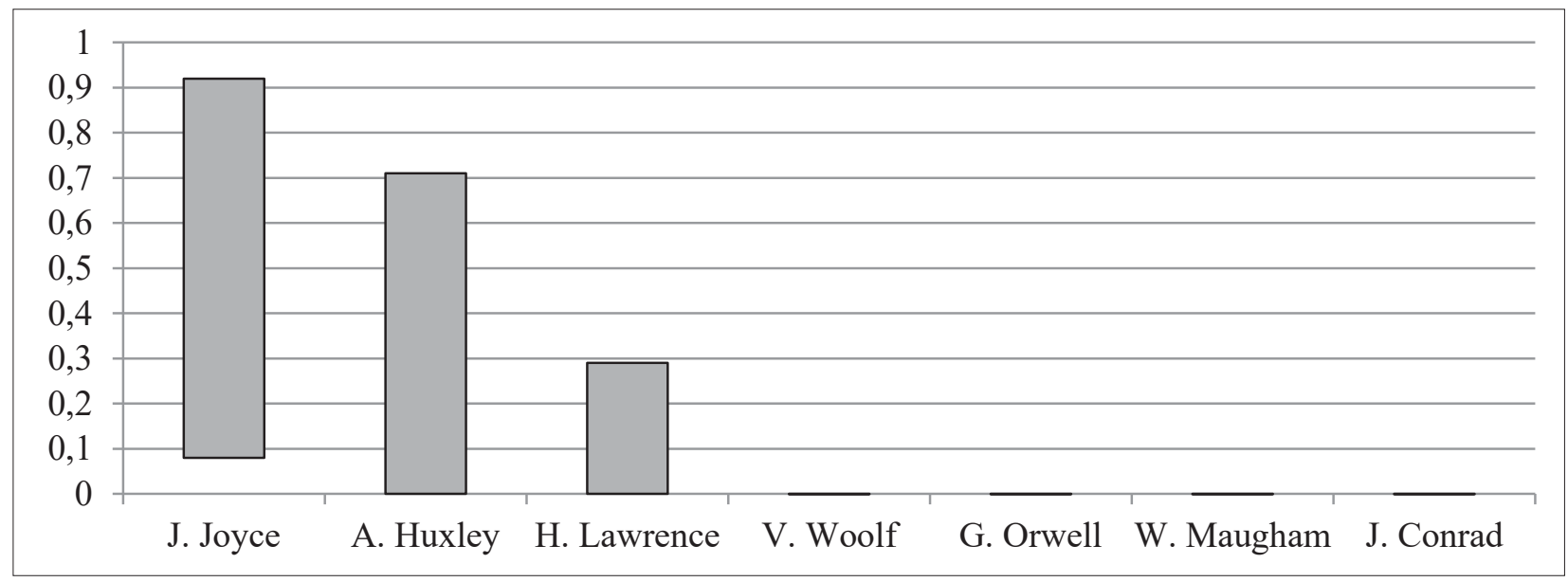

Fig. 1. The fluctuations of the sample mean of the mythological type of allusion in the epic texts

Distribution of independent FI (in \%)

\begin{tabular}{|l|l|l|l|l|l|l|l|}
\hline Author & J. Joyce & A. Huxley & H. Lawrence & V. Woolf & G. Orwell & S. Maugham & J. Conrad \\
\hline J. Joyce & & 0,64 & 1,77 & 2,21 & 2,21 & 2,21 & 2,21 \\
\hline A. Huxley & - & & 0,94 & 1,41 & 1,41 & 1,41 & 1,41 \\
\hline H. Lawrence & - & - & & - & - & - & - \\
\hline V. Woolf & - & - & - & & - & - & - \\
\hline G. Orwell & - & - & - & - & & - & - \\
\hline S. Maugham & - & - & - & - & - & & - \\
\hline J. Conrad & - & - & - & - & - & - & \\
\hline
\end{tabular}


On the basis of compared tale data it may be stated that in the pairs of J. Joyce - V. Woolf, J. Joyce - G. Orwell, J. Joyce - S. Maugham, J. Joyce - J. Conrad we observe the tendency to divergence. The other pairs of subsamples have the coefficient that is lower than the table one $t_{5 \%}$, and the divergence between them is insufficient. Thus they refer to one population, and the author's prefernces and genre differnece do not influence them.

3.2. Theological type of allusion. Religion-themed allusions are mostly spread in the epic genre of the Modernist literature and belong to the nucleus in the texts of various authors.

The coefficient of the standard error of the sample mean also varies in each subsample: 1,57 - J Joyce, 0,39 - A. Huxley, 0,51 - H. Lawrence, 0,95 - G. Orwell, 0,13 - S. Maugham, 0,16-J. Conrad.

The confidence intervals $\bar{x}-2 \delta_{-}$to $\bar{x}+2 \delta_{-}$ are between 0,00 and 5,64 (at $\varepsilon \%-98,77 \%$ ) - in J. Joyce's subsample; from 0,33 to 1,87 (at $\varepsilon \%-$ $99,31 \%$ ) - in A. Huxley subsample; from 0,37 to 2,43 (at $\varepsilon \%-99,31 \%$ ) - in H. Lawrence's texts; from 0,00 to 2,90 (at $\varepsilon \%-98,14 \%$ ) - in G. Orwell's novels; from 0,00 to 0,45 (at $\varepsilon \%-98,76 \%$ ) - in the texts of S. Maugham; from 0,18 to 0,82 (at $\varepsilon \%-$ $99,38 \%$ - in J. Conrad's prose. The frequency data are presented visually on the diagram (fig. 2).

Frequency parameters though differ in the range of the sample mean, but overlap as well. The distribution of different types of independent FI is presented in Table 2.
Differently spaced texts of A. Huxley and V. Woolf fix the distance between themselves almost at a zero value with an accuracy of $99 \%-0.02$. The tendency to the divergence is observed in pairs: V. Woolf $-\mathrm{H}$. Lawrence $\left(t_{2 \%} \leq t \leq t_{1 \%}\right)$, i.e. the accuracy of the divergence is $98.5 \%$. For the pair V. Wolf $-\mathrm{H}$. Lawrence $t \leq t_{1 \%}$, that shows only the tendency to the differgence. The greatest indicator of divergence is observed in the pair of G. Orwell -S. Maugham (0.52). For other pairs of samples we accept the null hypothesis.

3.3. Literary type of allusion. Allusions to the scenes, characters of other writers occupy a prominent place in the epicgenre in general and in the texts of the analysed writers in particular. The standard error of the sample mean is as follows: 1,33 - in the works of J. Joyce, 0,38 - A. Huxley, 0,09- H. Lawrence, 1,48 - V. Woolf, 0,38 - G. Orwell, 0,21 S. Maugham, 0,09 - J. Conrad.

Confidence intervals $\bar{x}-2 \delta$ - to $\bar{x}+2 \delta$ - are in the range from 0,74 to 6,06 (at $\varepsilon^{x} \%-99,23 \%$ ) - for the sample mean of the studied unit in the works of J. Joyce; from 0,55 to 2,05 (at $\varepsilon \%-99,43 \%$ ) - for the sample mean of literary allusions in A. Huxley's works; from 0,00 to 0,29 (at $\varepsilon \%-98,14 \%$ ) - in H. Lawrence's prose; from 0,00 to 5,15 (at $\varepsilon \%-$ $98,68 \%)-$ in the texts of V. Woolf; from 0,00 to 1,36 (at $\varepsilon \%-98,73 \%$ ) - in G. Orwell's subsample; from 0,08 to 0,92 (at $\varepsilon \%-99,17 \%$ ) - in S. Maugham's texts; from 0,00 to 0,29 (at $\varepsilon \%-98,14 \%$ ) - in J. Conrad's subsamples.

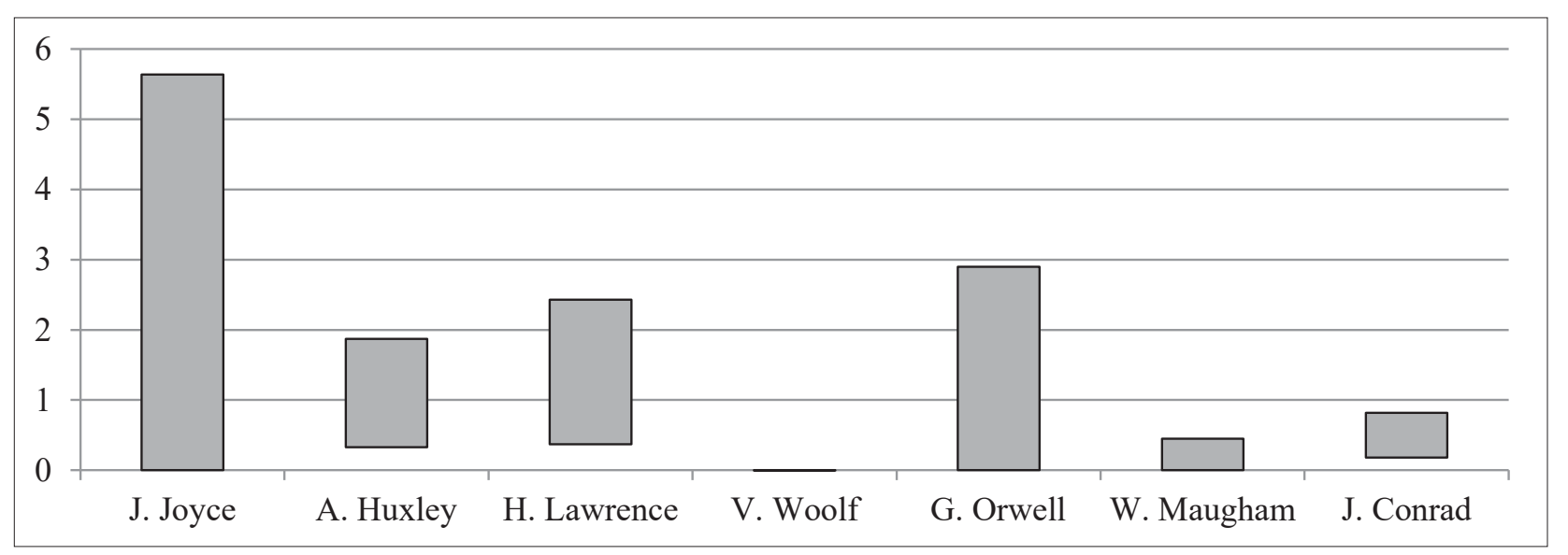

Fig. 2. The fluctuation of the sample mean of the theological type of allusion in the texts of the epic genre

Table 2

Distribution of independent FI (in \%)

\begin{tabular}{|l|c|c|c|c|c|c|c|}
\hline \multicolumn{1}{|c|}{ Author } & J. Joyce & A. Huxley & H. Lawrence & V. Woolf & G. Orwell & S. Maugham & J. Conrad \\
\hline J. Joyce & & 0,82 & 0,63 & 1,51 & 0,91 & 1,39 & 1,21 \\
\hline A. Huxley & - & & 0,44 & 2,70 & 2,25 & 2,10 & 1,47 \\
\hline H. Lawrence & - & - & & 2,58 & - & 2,15 & 1,66 \\
\hline V. Woolf & - & 0,02 & $+/-$ & & - & 1,50 & - \\
\hline G. Orwell & - & - & - & - & & 6,00 & - \\
\hline S. Maugham & - & - & - & - & 0,52 & & 2,25 \\
\hline J. Conrad & - & - & - & - & - & - & \\
\hline
\end{tabular}




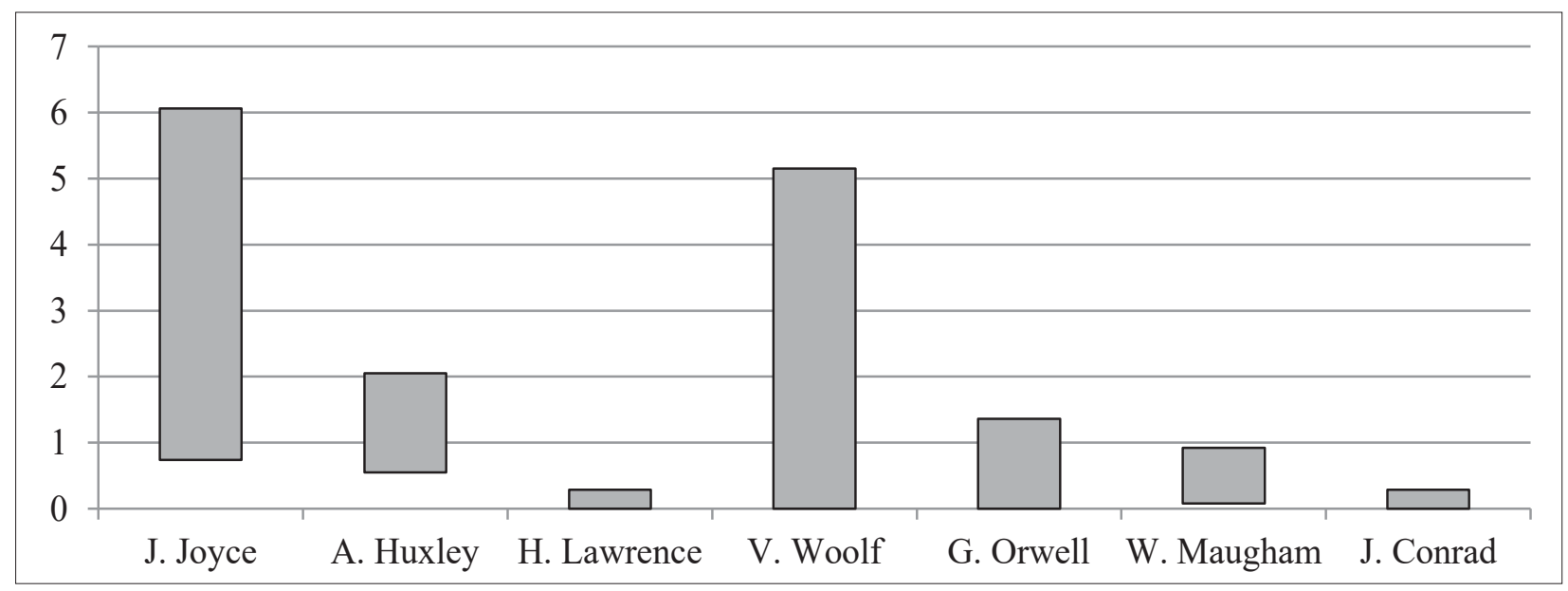

Fig. 3. The fluctuation of the sample mean of the literary type of allusion in the texts of the epic genre

Distribution of independent FI (in \%)

Table 3

\begin{tabular}{|l|c|c|c|c|c|c|c|}
\hline \multicolumn{1}{|c|}{ Author } & J. Joyce & A. Huxley & H. Lawrence & V. Woolf & G. Orwell & S. Maugham & J. Conrad \\
\hline J. Joyce & & 1,44 & 2,35 & 0,57 & 1,84 & 2,04 & 2,35 \\
\hline A. Huxley & - & & 2,94 & 0,56 & 0,99 & 1,76 & 2,94 \\
\hline H. Lawrence & - & 0,10 & & 1,35 & 0,96 & 1,62 & 0,00 \\
\hline V. Woolf & - & - & - & & 0,96 & 1,08 & 1,35 \\
\hline G. Orwell & - & - & - & - & & 0,16 & 0,84 \\
\hline S. Maugham & - & - & - & - & - & & 1,62 \\
\hline J. Conrad & - & 0,10 & - & - & - & - & \\
\hline
\end{tabular}

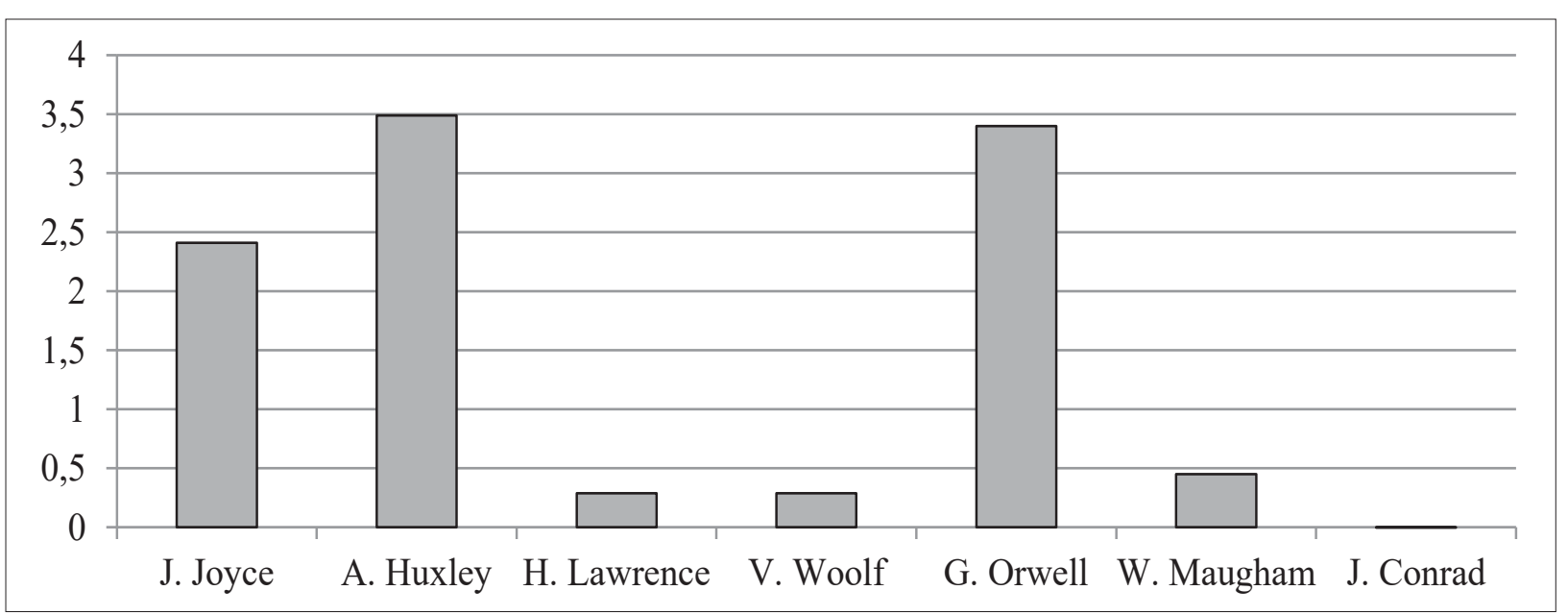

Fig. 4. The fluctuation of the sample mean of the historical type of allusion in the texts of the epic genre

Distribution of independent FI (in \%)

Table 4

\begin{tabular}{|l|l|l|l|l|l|l|l|}
\hline Author & J. Joyce & A. Huxley & H. Lawrence & V. Woolf & G. Orwell & S. Maugham & J. Conrad \\
\hline J. Joyce & & 0,51 & 1,43 & 1,43 & 0,53 & 1,28 & 1,59 \\
\hline A. Huxley & - & & 1,69 & 1,56 & 0,00 & 1,57 & 1,80 \\
\hline H. Lawrence & - & - & & 0,00 & 1,78 & 0,60 & 1,00 \\
\hline V. Woolf & - & - & - & & 1,78 & 0,59 & 0,95 \\
\hline G. Orwell & - & - & - & - & & 1,66 & 1,90 \\
\hline S. Maugham & - & - & - & - & - & & 1,50 \\
\hline J. Conrad & - & - & - & - & - & - & \\
\hline
\end{tabular}


Graphically confidence intervals may be marked on the range scale (fig. 3).

The distribution of different types of independent FI is presented in Table 3.

3.4. Historical and social type of allusion. The active usage of hints to historical and social events is a common feature for modernist prose writers, since the theme of war and social repercussions of the past and present attracted the writers of the period. Against this backdrop, the historical and social type of allusion is a relatively frequent unit in the workd of writers presented.

The standard error of the sample mean $\left(\delta_{\bar{x}}\right)$ of the historical type of allusions in the 0,66 in the writings of J. Joyce; 0,90 - A. Huxley; 0,09- H. Lawrence; 0,09-V. Woolf; 0,85-G. Orwell; 0,13-S. Maugham.

The confidence intervals $x-2 \delta_{\bar{x}}$ to $x+2 \delta_{-}$range from 0,00 to 2,41 (at $\varepsilon \%-98,83 \%$ ) - in the texts of J. Joyce; from 0,00 to 3,49 (at $\varepsilon \%-98,97 \%$ ) - in the analysed subsamples of A. Huxley; from 0,00 to 0,29 (at $\varepsilon \%-98,14 \%$ ) - in the works of H. Lawrence; from 0,00 to 0,28 (at $\varepsilon \%-98,14 \%$ ) - in the texts of V. Woolf; from 0,00 to 3,40 (at $\varepsilon \%-99,02 \%$ ) in the subsamples of G. Orwell; from 0,00 to 0,45 (at $\varepsilon \%-98,76 \%$ ) - in S. Maugham's texts.

The confidence intervals are visually presented on the diagram (fig. 4).

The distribution of different types of independent FI is presented in Table 4.

Significant divergences according to the given table are not observed in any pair of samples of the writers, and therefore, in relation to this type of allusions, they are close to each other, and the coefficients of divergences are not their statistical parameters.

3.5. Folklore type of allusion. This type is characteristic of the texts of such authors as J. Joyce, A. Huxleyand H. Lawrence.

The standard error of the sample mean $\left(\delta_{\overline{-}}\right)$ is 0,28 for the texts of J. Joyce, 0,09 - for the texts of A. Huxley and $0,28-$ for $\mathrm{H}$. Lawrence prose.

The confidence intervals $x-2 \delta_{\bar{x}}$ to $x+2 \delta_{-}$is fixed in the range from 0,13 to 1,27 (at $\varepsilon \%-99,20 \%$ ) in J. Joyce's texts; from 0,00 to 0,29 (at $\varepsilon \%-$ $98,14 \%$ - in A. Huxley's subsamples; from 0,00 to 0,87 (at $\varepsilon \%-98,14 \%$ ) - in H. Lawrence's prose.

The diagram shows the fluctuations of the bandwidths of allusions in the subsamples (fig. 5).

The distribution of different types of independent FI is presented in Table 5.

Among the obtained confidence intervals coefficients, the most interesting indicators are observed by comparing J. Joyce's prose with that of V. Woolf, J. Orwell, S. Maugham and J. Conrad, since the last four authors did not have this type of allusions. The indicator is $t_{2,5 \%}<t<t_{2 \%}$, thus it is fair to determine that the phenomenon has a tendency to diverge. The other ten matching pairs are subject to the laws of the null hypothesis.

3.6. Everyday-life type of allusion. Allusions to the objects of the surrounding world are a qualitative feature for J. Joyce's prose, since the absolute frequency reaches 17 units for 10 subsamples.

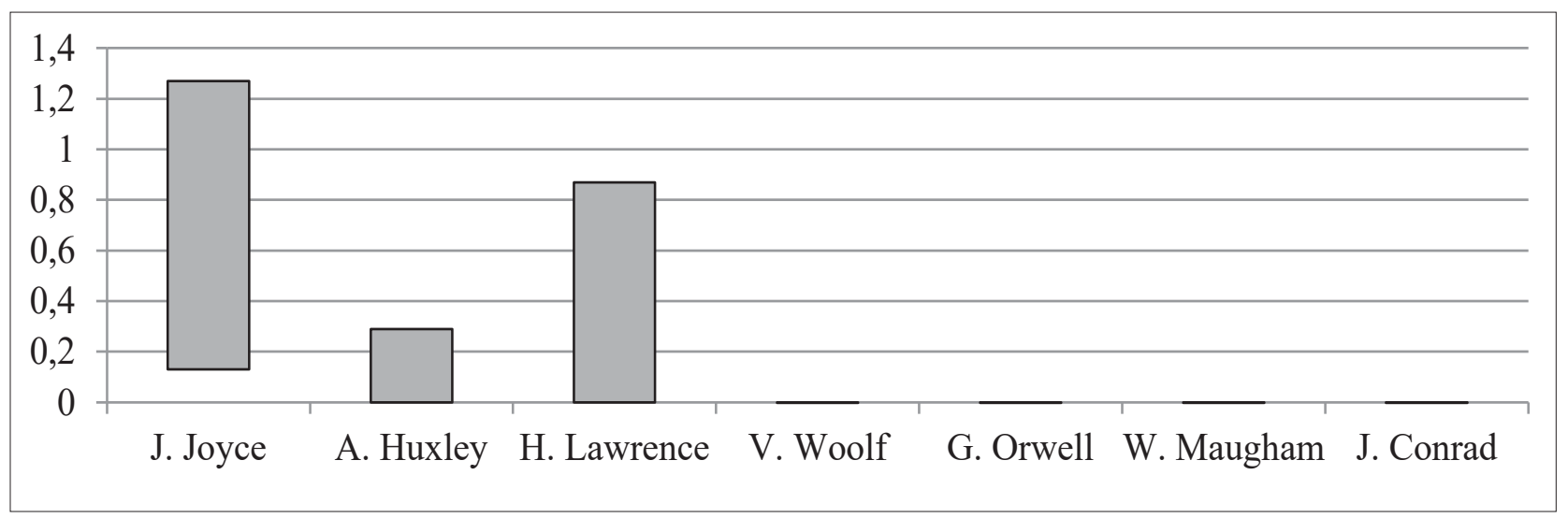

Fig. 5. The fluctuation of the sample mean of the folklore type of allusion in the texts of the epic genre

Table 5

Distribution of independent FI (in \%)

\begin{tabular}{|l|c|c|c|c|c|c|c|}
\hline \multicolumn{1}{|c|}{ Author } & J. Joyce & A. Huxley & H. Lawrence & V. Woolf & G. Orwell & S. Maugham & J. Conrad \\
\hline J. Joyce & & 1,90 & 0,94 & 2,33 & 2,33 & 2,33 & 2,33 \\
\hline A. Huxley & - & & 0,63 & 1,00 & 1,00 & 1,00 & 1,00 \\
\hline H. Lawrence & - & - & & 1,00 & - & 1,00 & 1,00 \\
\hline V. Woolf & $+/-$ & - & - & & - & - & - \\
\hline G. Orwell & $+/-$ & - & - & - & & - & - \\
\hline S. Maugham & $+/-$ & - & - & - & - & & - \\
\hline J. Conrad & $+/-$ & - & - & - & - & - & \\
\hline
\end{tabular}




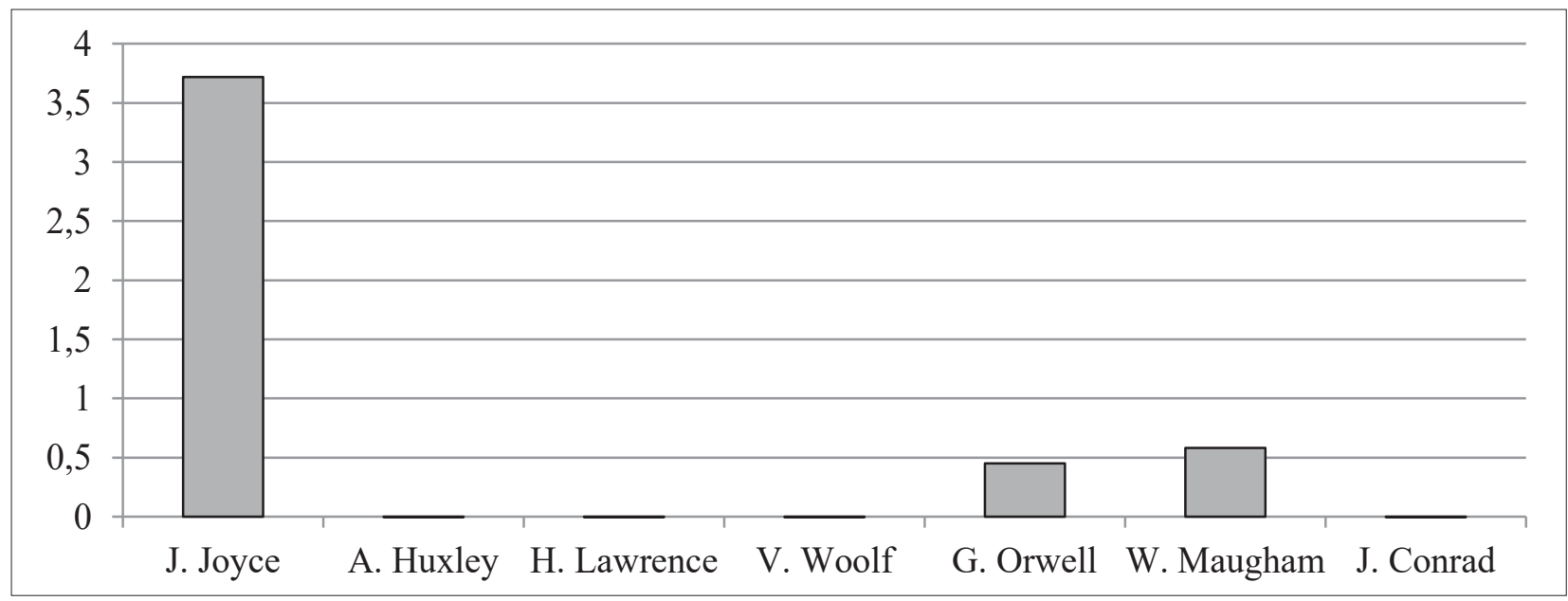

Fig. 6. The fluctuation of the sample mean of the everyday-life type of allusion in the texts of the epic genre

Table 6

Distribution of independent FI (in \%)

\begin{tabular}{|l|c|c|c|c|c|c|c|}
\hline \multicolumn{1}{|c|}{ Author } & J. Joyce & A. Huxley & H. Lawrence & V. Woolf & G. Orwell & S. Maugham & J. Conrad \\
\hline J. Joyce & & 1,52 & 1,52 & 1,52 & 1,33 & 1,33 & 1,52 \\
\hline A. Huxley & - & & - & - & 1,50 & 1,00 & - \\
\hline H. Lawrence & - & - & & - & 1,50 & 1,00 & - \\
\hline V. Woolf & - & - & - & & 1,50 & 1,00 & - \\
\hline G. Orwell & - & - & - & - & & 0,00 & 1,50 \\
\hline S. Maugham & - & - & - & - & - & & 1,00 \\
\hline J. Conrad & - & - & - & - & - & - & \\
\hline
\end{tabular}

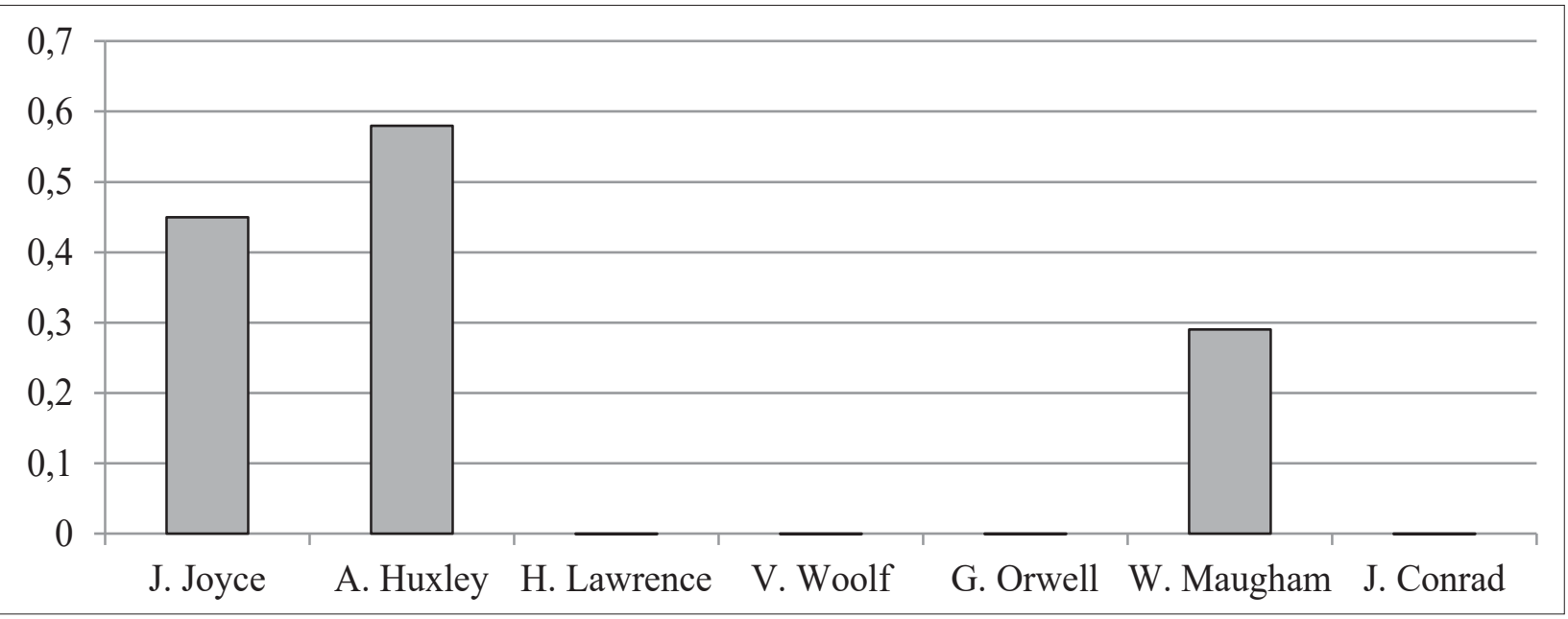

Fig.7. The fluctuation of the sample mean of the art type of allusion in the texts of the epic genre

Distribution of independent FI (in \%)

Table 7

\begin{tabular}{|l|c|c|c|c|c|c|c|}
\hline \multicolumn{1}{|c|}{ Author } & J. Joyce & A. Huxley & H. Lawrence & V. Woolf & G. Orwell & S. Maugham & J. Conrad \\
\hline J. Joyce & & 0,00 & 1,50 & 1,50 & 1,50 & 0,60 & 1,50 \\
\hline A. Huxley & - & & 1,00 & 1,00 & 1,00 & 0,45 & 1,00 \\
\hline H. Lawrence & - & - & & - & - & 1,00 & - \\
\hline V. Woolf & - & - & - & & - & 1,00 & - \\
\hline G. Orwell & - & - & - & - & & 1,00 & - \\
\hline S. Maugham & - & - & - & - & - & & 1,00 \\
\hline J. Conrad & - & - & - & - & - & - & \\
\hline
\end{tabular}


The fraction of the division of the mean square deviation to the square root of the number of excerpts studied, or the standard error of the sample mean $\left(\delta_{\bar{x}}\right)$ of the everyday-life type of allusion in the texts of J. Joyce equals 1,01 , in G. Orwell's texts $-0,13$, in S. Maugham's texts $-0,19$.

The confidence intervals $\bar{x}-2 \delta_{\bar{x}}$ to $\bar{x}+2 \delta_{\bar{x}}$ are in the range from 0,00 to 3,72 (at $\varepsilon \%-98,83 \%$ ) in J. Joyce's novels; from 0,00 to 0,45 (at $\varepsilon \%-$ $98,76 \%$ - in G. Orwell's subsamples; from 0,00 to 0,58 (at $\varepsilon \%-98,14 \%$ ) - in S. Maugham's texts.

It is clear that at such similar frequency range they intersect each other, as shown on the diagram (fig. 6).

The contrast of the upper bound of the sample mean range of the everyday-life type of allusions in J. Joyce's texts to the range of the sample mean in the texts of other authors however does not indicate that the divergence will be high, since the frequencies cross. The distribution of different types of independent FI is presented Table 6.

All empirical values are $t<t_{5 \%}$, that is, we have the basis for grouping all sub-samples into one sample, although in some texts this type of allusions does not function at all.

3.7. Art allusion. The analysed type of allusions is similar to the characteristics of the folklore one and is not decisive within the texts of modernist prose writers.

The standard error of the sample mean $\left(\delta_{\bar{x}}\right)$ in the sample of J. Joyceis 0,13, in A. Huxley's sample 0,19 , and in S. Maugham's sample - 0,09.
The confidence intervals $\bar{x}-2 \delta$ - to $\bar{x}+2 \delta$ - range from 0,00 to 0,45 (at $\varepsilon \%-98,76 \%$ ) in J. Joyce's texts; from 0,00 to 0,58 (at $\varepsilon \%-98,14 \%$ ) - in A. Huxley's prose; from 0,00 to 0,29 (at $\varepsilon \%-$ $98,14 \%)-$ in the texts of S. Maugham.

Graphically the confidence intervals are presented on the diagram (fig. 7).

The distribution of different types of independent FI is presented in Table 7.

We cannot appeal to the tendency of divergence, since the coefficients of divergence are not high and therefore indicate the similarity of the texts themselves with respect to this stylistic object.

3.8. Personal allusion. The personal type of allusions is present in the work of most writers, namely in six of the seven submitted for consideration and is included in the main system of the types of allusion.

The standard error of the sample mean $\left(\delta_{\bar{x}}\right)$ in J. Joyce's prose is 0,42 , in A. Huxley's texts 0,44 , in H. Lawrence's works - 0,19 , in V. Woolf's prose $-0,40$, in G. Orwell's sample - 0,45, and in S. Maugham's sample $-0,57$.

The confidence intervals $\bar{x}-2 \delta_{\bar{x}}$ to $\bar{x}+2$ $\delta_{\bar{x}}$ range from 0,36 to 2,04 (at $\varepsilon \%-99,31 \%$ ) in J. Joyce's prose; from 0,31 to 2,09 (at $\varepsilon \%-$ $99,28 \%$ - in A. Huxley's works; from 0,00 to 0,58 (at $\varepsilon \%-98,14 \%$ ) - in H. Lawrence's texts; from 0,00 to 1,50 (at $\varepsilon \%-98,88 \%$ ) - in V. Woolf's prose; from 0,00 to 1,60 (at $\varepsilon \%-98,74 \%$ ) - in G. Or-

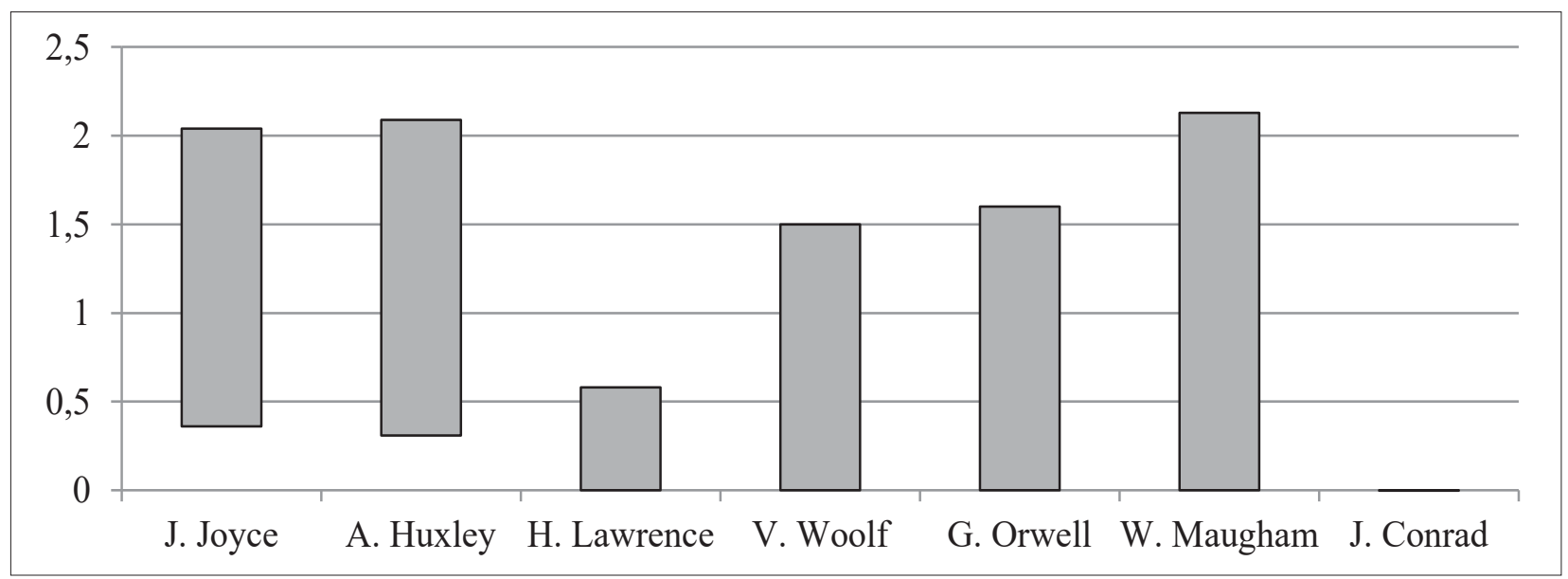

Fig. 8. The fluctuation of the sample mean of the personal type of allusion in the texts of the epic genre

Distribution of independent FI (in \%)

Table 8

\begin{tabular}{|l|c|c|c|c|c|c|c|}
\hline \multicolumn{1}{|c|}{ Author } & J. Joyce & A. Huxley & H. Lawrence & V. Woolf & G. Orwell & S. Maugham & J. Conrad \\
\hline J. Joyce & & 0,00 & 2,06 & 0,82 & 0,77 & 0,27 & 2,71 \\
\hline A. Huxley & - & & 1,97 & 0,79 & 0,75 & 0,26 & 2,57 \\
\hline H. Lawrence & - & - & & 1,07 & 0,00 & 1,27 & 1,00 \\
\hline V. Woolf & - & - & - & & 0,00 & 0,41 & 1,66 \\
\hline G. Orwell & - & - & - & - & & 0,39 & 1,48 \\
\hline S. Maugham & - & - & - & - & - & & 1,68 \\
\hline J. Conrad & $+/-$ & $+/-$ & - & - & - & & - \\
\hline
\end{tabular}


well's texts; from 0,00 to 2,13 (at $\varepsilon \%-98,89 \%$ ) - in S. Maugham's texts.

The frequency chart, however, does not capture significant differences (fig. 8).

The distribution of different types of independent FI is presented in Table 8.

With the help of the obtained indicators, the interpretation of the divergence insignificance is valid for all analysed pairs, with the exception of the opposition of the texts by A. Huxley - J. Conrad and J. Joyce - J. Conrad, which are characterized by a degree of divergence with a relative inaccuracy of about $2,5 \%\left(t_{2 \%}<t<t_{1 \%}\right)$.

4. Conclusions. Consequently, the analysis carried out in the field of the comparison of the allusive tendencies in the texts belonging to the epic genre of the British modernist writers, is marked by a somewhat greater variation than a similar study between the plays of British playwrights of the same period.

To answer the question about the reasons for the significance of the divergence between the pairs of comparable samples, it is necessary to first determine the qualitative factors of influence on the author, which formed his artistic consciousness.

In the texts of the English-speaking writers of the twentieth centurythe attitude of people of a complex socio-historical epoch, filled with a large number of significant events and changes that took place after them (wars, collapse of empires, revolutions, penetration into new fields of scientific knowledge and the essence of man) is reflected. Therefore, the attention of J. Joyce, H. Lawrence, A. Huxley and G. Orwell, a large part of the novels of whom corresponds to the historical and social themes, focuses on the inner world of a man and the peculiarities of his psychology in terms of hostilities, conflicts of industrial civilization of the era.

We can clearly state that the projection of biblical plots in J. Joyce's prose serves as a kind of reminder to a man of the actions of the life of the saints. At the same time, a large number of literary allusions in the work of this author I. I. Garin explains as the direction of J. Joyce to the work of Shakespeare that is treated to be the main building material of "Ulysses" (Harin 2002) ${ }^{16}$, as well as H. Ibsen, "Decameron"of G. Boccaccio,works of P. Shelley, poetry by J. Byron, T. Moore, S. Mallarme, A. Tennyson, R. Browning and others.

The absence of the historical and social type of allusions in the work of J. Conrad is connected with the period of writing the "Heart of Darkness" (1899), "The Secret Agent" (1907), "Under Western Eyes" (1911), which he created before the beginning of the war, and therefore this subject has not yet acquired such a broad mass as during the creative activity of G. Orwell or A. Huxley. J. Conrad stands at the root of modernism; therefore, the characteristic of the allusive load inherent in the main group of British modernists is not present on the pages of his epic.

Confirmation of the fact that the form of the work affects the allusive load is also based on a comparison of the combination of the average frequency of the types of allusions in the work of S. Maugham, when comparing his drama and narrative texts. According to V. I. Perebyinis (Perebyinis 2002) ${ }^{17}$, the coefficient of determining the differences between two samples for comparing the works of one author can be determined by dividing the total number of average frequencies of allusions operating in one genre by the same number of those that function in another. For S. Maugham's texts, this particle will be $2,10 / 0,60$ $=3,25$, that is, the higher the value, the greater will be the distance from one sample to another. In other words, the formation of an allusive layer of a text is directly proportional to the linguistic laws of the language, structural features of sentences, their grammar, as well as the forms of expression of the text.

\section{BIBLIOGRAPHY}

Алексієнко Л. А., Дарчук Н. П. Принципи створення параметризованої бази даних за поетичними текстами Лесі Українки // Леся Українка і сучасність (До 130-річчя від дня народження Лесі Українки): Зб. наук. пр.- Луцьк: Волин. обл. друк., 2004. - С. 344-352.

Гарин И. И. Век Джойса / И. И. Гарин. - М. : ТЕРРА-Книжный клуб, 2002. - 848 с.

Головин Б. Н. Введение в языкознание. - Москва: Высш. шк., 1977. - 331 с.

Демська-Кульчицька О. Що таке корпус текстів [Electronic resource] / О. Демська-Кульчицька. - Access mode: http://kulturamovy.univ.kiev.ua/KM/pdfs/Magazine64-7.pdf

Жуковська В.В.Лексико семантичні та прагматичні характеристики англійського дієслова у художньому тексті : лінгвостатистичний аспект (на матеріалі популярних політичних романів) : дис. ... канд. філол. наук : 10.02 .04 / Вікторія Вікторівна Жуковська. - К., 2006. - 307 с.

Левицький В.В. Квантитативные методы в лингвистике / В. В. Левицький. - Вінниця: Нова Книга, 2007. - 259 с.

Перебийніс В. І. Статистичні методи для лінгвістів / В. І. Перебийніс. - Вінниця: Нова книга, 2002. - 168 с.

Baayen, Harald R. Analyzing linguistic data: A practical introduction to statistics using R / H.R. Baayen. - Cambridge: Cambridge University Press, 2008. - 296 p.

Gries, Stefan Th. Statistics for linguistics with R: A practical introduction (2nd, revised edition) / S. Th. Gries. - Berlin \& Boston, MA: De Gruyter Mouton, 2013. - 359 p.

\footnotetext{
${ }^{16}$ Harin, I. I. (2002). VekDzhoisa. Moskva: TERRA-Knizhnyiklub.

${ }^{17}$ Перебийніс, В. І. Статистичні методи для лінгвістів, Вінниця, Нова книга, 2002, 168 с. (Perebyinis 2002)
} 
Johnson K. Quantitative methods in linguistics / K. Johnson. - Malden: Blackwell Publishing, 2008. - 278 p.

Pande, H., Hoshiyar D. Determination of the Distribution of Sentence Length Frequencies for Hindi Language Texts and Utilization of Sentence Length Frequency Profiles for Authorship Attribution / H. Pande, D. Hoshiyar // Journal of Quantitative Linguistics. 2015. - Vol. 22 (4). - P. 338-348

Pascual, C.G. (Ed.). Statistical Methods in Language and Linguistic Research / C. G. Pascual. - UK: Equinox Publishing Ltd, 2013. $-260 \mathrm{p}$.

Pigoli D., Hadjipantelis, P. Z., Coleman, J. S. and Aston, J. A. D. The statistical analysis of acoustic phonetic data: exploring differences between spoken Romance languages / D. Pigoli, Z. Hadjipantelis, J. S. Coleman and J. A. D. Aston // Journal of the Royal Statistical Society: Series C (Applied Statistics). - 2018. - Vol. 67 (Part 4). - P. 1-27

Popescu, I.-I. Quantitative Analysis of Poetic Texts / I.-I. Popescu. - Berlin \& Boston, MA: Walter De Gruyter Incorporated, 2015. -280 p.

Rovenchak, A., Buk, S. Part-of-Speech Sequences in Literary Text: Evidence From Ukrainian / A. Rovenchak, S. Buk // Journal of Quantitative Linguistics. - 2018. - Vol. 25 (1). - P. 1-21

Upton, G., Cook I. Introducing Statistics / G. Upton, I. Cook. - Oxford: Oxford University Press, 2001. - 480 p.

\section{REFERENCES}

Baayen, Harald R. (2008). Analyzing linguistic data: A practical introduction to statistics using R . Cambridge: Cambridge University Press.

Gries, Stefan Th.(2013). Statistics for linguistics with R: A practical introduction (2nd, revised edition).Berlin \& Boston, MA:

De Gruyter Mouton.

Johnson K. (2008). Quantitative methods in linguistics / K. Johnson. Malden: Blackwell Publishing.

Pande, H., Hoshiyar D. (2015). Determination of the Distribution of Sentence Length Frequencies for Hindi Language Texts and Utilization of Sentence Length Frequency Profiles for Authorship Attribution. In Journal of Quantitative Linguistics, 22 (4), pp. 338-348.

Pascual, C.G. (Ed.) (2013). Statistical Methods in Language and Linguistic Research. UK: Equinox Publishing Ltd.

Pigoli D. (2018). The statistical analysis of acoustic phonetic data: exploring differences between spoken Romance languages. In Journal of the Royal Statistical Society: Series C (Applied Statistics), 67 (Part 4), pp. 1-27.

Popescu, I.-I. (2015). Quantitative Analysis of Poetic Texts. Berlin \& Boston, MA: Walter De Gruyter Incorporated.

Rovenchak, A., Buk, S. (2018). Part-of-Speech Sequences in Literary Text: Evidence From Ukrainian. In Journal of Quantitative Linguistics. Vol. 25 (1), pp. 1-21

Upton, G., Cook I. (2001). Introducing Statistics. Oxford: Oxford University Press.

Aleksiienko, L. A. (2003). Pryntsypy stvorennia parametryzovanoi bazy danykh za poetychnymy tekstamy Lesi Ukrainky. In Lesia Ukrainka i suchasnist (do 130-richchia vid dnia narodzhennia Lesi Ukrainky) : zb. nauk. prats. Lutsk : Volyn. obl. druk., pp. 344-352. Harin, I. I. (2002). Vek Dzhoisa [Век Джойса]. Moskva: TERRA-Knizhnyi klub.

Holovin, B. N. (1977). Vvedenie v jazikoznaniye [Введение в языкознание]. Moskva: Vussh. shk.

Demska-Kulchytska, O. Shcho take korpus tekstiv? [Що таке корпус текстів][Electronic resource]. - Access mode: http://kulturamovy.univ.kiev.ua/KM/pdfs/Magazine64-7.pdf

Zhukovska, V. V. (2006). Leksyko-semantychni ta prahmatychni kharakterystyky anhliyskoho diyeslova u khudozhniomu teksti: linhvo-statystychnyi aspect (na materiali populiarnykh politychnukh romaniv) [Лексико семантичні та прагматичні характеристики англійського дієслова у художньому тексті : лінгвос- татистичний аспект (на матеріалі популярних політичних романів)]: dys. ... kand. filol. nauk: 10.02.04. Kyiv.

Levytskyi, V.V. (2007). Kvantitativnie metody v lingvistike [Квантитативные методы в лингвистике]. Vinnytsia: Nova knyha

Perebyinis,V. I. (2002). Statystychni metody dlia linhvistiv [Статистичні методи для лінгвістів]. Vinnytsia: Nova knyha.

\section{Анотація}

Дослідження присвячене аналізу алюзивного навантаження в текстах англійських письменників-модерністів. Незважаючи на те, що значна кількість лінгвістичних досліджень уже проведена у цій галузі, статистичний аспект досі не був визначений як основний у аналізі алюзій. Матеріал, використаний для дослідження, базується на десяти випадково вибраних фрагментах текстів семи авторів (70 фрагментів загалом). Вибір матеріалу здійснювався за визначеними лінгвістичними критеріями. Для отримання статистично достовірних результатів застосовувалася серія обчислень, зокрема критерій Стьюдента (t-тест) показав відстань між аналізованими парами авторів та алюзивною навантаженістю їх текстів. 3 метою ідентифікації екстралінгвістичного впливу на обсяг алюзій, виявлених в текстах, ми виокремили вісім типів алюзій: міфологічного, теологічного, літературного, історично-соціального, фольклорного, побутоовго, арт та особового. Можна чітко сказати, що проекція біблійних, історичних або літературних сюжетів у художніх творах британських авторівмодерністів відображає поточний стан епохи, а також вказує на індивідуально-авторські особливості та інтертекстуальну кореляцію їхніх творів з попередніми літературними текстами. Результати засвідчили, що епічний жанр характеризується літературними, теологічними, історичними та особовими типами алюізй. Переважність теологічних, літературних і побутового типів алюзій характерна длятекстів Дж. Джойс, літературного та історичного типів - О. Хакслі, історичного типу Дж. Орвелла, літературного - В. Вулф. За допомогою отриманих показників виявлено, що майже усі аналізовані пари вибірок характеризуються статистичною подібністю, за винятком протиставлення текстів О. Хакслі - В. Вулф $(0,02) \mathrm{i}$ Дж. Орвелла - С. Моема $(0,52)$ в теологічному типі алюзій, О. Хакслі й Г. Лоуренса $(0,1)$, О. Хакслі та Дж. Конрада $(0,1)$ у літературному типі. Залежність дистрибуції алюзій від жанрової організації тексту підтверджується й фактом відмінностіалюзивної навантаженості при порівнянні драматургії та творів епічного жанру С. Моема в бік переважання останнього.

\section{Ключові слова}

Алюзія, інтертекст, модернізм, t-тест, статистична значущість. 